\title{
Interactions between Hedgehog proteins and their binding partners come into view
}

\author{
Philip A. Beachy, ${ }^{1,2}$ Sarah G. Hymowitz, ${ }^{3}$ Robert A. Lazarus, ${ }^{4}$ Daniel J. Leahy, ${ }^{5,7}$ \\ and Christian Siebold ${ }^{6}$ \\ ${ }^{1}$ Department of Developmental Biology, Institute for Stem Cell Biology and Regenerative Medicine, Stanford University School \\ of Medicine, Stanford, California 94305, USA; ${ }^{2}$ Howard Hughes Medical Institute, Stanford University School of Medicine, \\ Stanford, California 94305, USA; ${ }^{3}$ Department of Structural Biology, Genentech, South San Francisco, California 94080, USA; \\ ${ }^{4}$ Department of Protein Engineering, Genentech, South San Francisco, California 94080, USA; ${ }^{5}$ Department of Biophysics and \\ Biophysical Chemistry, Johns Hopkins University School of Medicine, Baltimore, Maryland 21205, USA; ${ }^{6}$ Division of Structural \\ Biology, Wellcome Trust Centre for Human Genetics, University of Oxford, Oxford OX3 7BN, United Kingdom
}

\begin{abstract}
Hedgehog (Hh) proteins are secreted signaling molecules that mediate essential tissue-patterning events during embryonic development and function in tissue homeostasis and regeneration throughout life. Hh signaling is regulated by multiple mechanisms, including covalent lipid modification of the $\mathrm{Hh}$ protein and interactions with multiple protein and glycan partners. Unraveling the nature and effects of these interactions has proven challenging, but recent structural and biophysical studies of $\mathrm{Hh}$ proteins and active fragments of heparin, Ihog, Cdo, Boc, Hedgehoginteracting protein (Hhip), Patched (Ptc), and the monoclonal antibody 5E1 have added a new level of molecular detail to our understanding of how Hh signal response and distribution are regulated within tissues. We review these results and discuss their implications for understanding $\mathrm{Hh}$ signaling in normal and disease states.
\end{abstract}

The hedgehog gene (hh) was identified in a now classic screen for genes that specify the formation of embryonic pattern in the fruit fly, Drosophila melanogaster, and named for an abnormal bristle pattern in hh mutant larvae (Nusslein-Volhard and Wieschaus 1980). Isolation of the $h h$ gene revealed it to encode a secreted protein expressed in segmentally repeated stripes, consistent with its role in specifying segmental pattern (Lee et al. 1992; Mohler and Vani 1992; Tabata et al. 1992; Tashiro et al. 1993). Following signal sequence cleavage and entry into the secretory pathway, the Hh protein undergoes an autoprocessing event in which a $45-\mathrm{kDa}$ precursor cleaves itself into an N-terminal fragment of $19 \mathrm{kDa}$ $(\mathrm{HhN})$ that retains all signaling activity and a C-terminal fragment of $25 \mathrm{kDa}$ (HhC) (Lee et al. 1992, 1994; Bumcrot et al. 1995; Porter et al. 1995). This reaction also results in covalent attachment of cholesterol to the $\mathrm{C}$ terminus of

[Keywords: Hedgehog; Ihog; Cdo; Hhip; X-ray crystallography; Hedgehog receptor]

${ }^{7}$ Corresponding author.

E-MAIL dleahy@jhmi.edu; FAX (410) 614-8839.

Article is online at http://www.genesdev.org/cgi/doi/10.1101/gad.1951710.
HhN (Porter et al. 1996; for review, see Mann and Beachy 2004). HhN is further modified by palmitoylation at its $\mathrm{N}$ terminus (Pepinsky et al. 1998), and a separate acyltransferase required for palmitoylation has been identified (Amanai and Jiang 2001; Chamoun et al. 2001; Lee et al. 2001; Micchelli et al. 2002; Buglino and Resh 2008). The resulting lipid-modified $\mathrm{HhN}$ requires at least one factor for release from its site of synthesis (the protein Dispatched) (Burke et al. 1999), and released HhN appears to be multivalent and part of a lipoprotein complex /Chen et al. 2004; Panakova et al. 2005).

The three hedgehog homologs present in mammalsSonic hedgehog (Shh), Indian hedgehog (Ihh), and Desert hedgehog (Dhh) —are similarly processed, modified, and released (for review, see Mann and Beachy 2004), and they also mediate many developmental patterning events (for reviews, see Muenke and Beachy 2001; McMahon et al. 2003; Varjosalo and Taipale 2008 and references therein). Shh in particular has drawn much interest as the key morphogenetic factor elaborated by several well-known organizing centers, including the zone of polarizing activity in the limb bud, the notochord and prechordal plate within axial mesoderm, and the floor plate and ventral forebrain within the neural tube (Echelard et al. 1993; Krauss et al. 1993; Riddle et al. 1993; Chang et al. 1994; Roelink et al. 1994). Loss of Shh function thus causes cyclopia and other midline face and brain defects characteristic of holoprosencephaly, as well as loss of the axial skeleton, severe limb patterning defects, and other malformations (Chiang et al. 1996). Ihh plays a role in long-bone growth, cartilage development, and, in conjunction with Shh, midline specification (St-Jacques et al. 1999; Zhang et al. 2001), and Dhh is required for normal development of peripheral nerves and germ cells in the testis (Bitgood et al. 1996; Parmantier et al. 1999). Please consult the reviews cited above and references therein for a more complete discussion of Hh patterning functions.

The vital and finely tuned tissue-patterning activities of Hedgehog proteins require strict spatial and temporal regulation, and multiple cell surface proteins have been 
implicated in receiving or modulating responses to Hedgehog signals (Fig. 1; for review, see Wilson and Chuang 2006). The core components that mediate Hedgehog signal response in Drosophila are Patched (Ptc), a 12-pass integral membrane protein (Hooper and Scott 1989; Nakano et al. 1989), and Smoothened (Smo), a seven-pass integral membrane protein with homology with G-protein-coupled receptors (Alcedo et al. 1996; van den Heuvel and Ingham 1996). Ptc and Smo orthologs have been identified in mammals, and are also core components of the Hh signaling pathway (Goodrich et al. 1996; Johnson et al. 1996; Stone et al. 1996). Ptc normally inhibits the activity of Smo, a positive regulator of Hedgehog pathway activation (Denef et al. 2000; Taipale et al. 2002). Hh relieves this inhibition (Ingham et al. 1991), leading to accumulation of Smo in the plasma membrane in Drosophila (Denef et al. 2000) and within the primary cilium in mammals (Corbit et al. 2005; Rohatgi et al. 2007), along with activation of downstream pathway components.

How signals are transmitted from $\mathrm{Hh}$ to Ptc to Smo remains unclear, and may not be fully conserved between vertebrates and invertebrates. Vertebrate $\mathrm{Hh}$ proteins appear to bind directly to cognate Ptc proteins (Marigo et al. 1996; Stone et al. 1996; Fuse et al. 1999), but attempts to detect a direct, binary interaction between Drosophila $\mathrm{HhN}$ (dHhN) and Drosophila Ptc (dPtc) have proven unsuccessful (Zheng et al. 2010). The apparent discrepancy between the sufficiency of mammalian and Drosophila Ptc for direct binding to $\mathrm{HhN}$ is at odds with the conserved genetic relationships among $\mathrm{Hh}$, Ptc, and Smo, but may be explained by the presence and function in Drosophila of Ihog and its homolog, Brother of Ihog (Boi), single-pass adhesion-like integral membrane proteins with extracellular immunoglobulin and fibronectin type III (FNIII) repeats. Ihog and Boi bind $\mathrm{HhN}$ with micromolar affinity and appear to function with Ptc as obligate coreceptors for $\mathrm{Hh}$ in Drosophila (Lum et al. 2003; McLellan et al. 2006; Yao et al. 2006; Zheng et al. 2010). Cdo and Boc, the closest vertebrate homologs of Ihog, bind vertebrate $\mathrm{Hh}$ proteins and play a positive role in Hh signaling (Cole and Krauss 2003; Tenzen et al. 2006; Yao et al. 2006; Zhang et al. 2006; Martinelli and Fan 2007; McLellan et al. 2008), but whether they synergize with Ptc for Hh binding is not yet firmly established, and some evidence suggests competition between Ptc and Cdo for binding to the N-terminal fragment of murine Shh (ShhN) (Cole and Krauss 2003; Tenzen et al. 2006; Yao et al. 2006; Zhang et al. 2006; Martinelli and Fan 2007; McLellan et al. 2008). How Ptc inhibits Smo-and how Hh relieves this inhibition-is also not well understood, although the ability of Ptc to inhibit a large stoichiometric excess of Smo suggests that inhibition does not occur through direct contact between Ptc and Smo (Denef et al. 2000; Ingham et al. 2000; Taipale et al. 2002).

In addition to the essential pathway components Ptc, Smo, and Ihog/Cdo, Hh signaling is modulated by several other cell surface components. Heparan sulfate proteoglycans (HSPGs) have been implicated in modulating Hh activity in both vertebrates and invertebrates (for review, see Filmus et al. 2008; Yan and Lin 2009). This observation is perhaps unsurprising given that Hh proteins bind heparin (Lee et al. 1994; Zhang et al. 2007), but the effect of HSPGs on Hh signaling may be positive or negative and may affect either responsiveness to $\mathrm{Hh}$ or the tissue distribution of $\mathrm{Hh}$ (Desbordes and Sanson 2003; Lum et al. 2003; Han et al. 2004; Beckett et al. 2008; Capurro et al. 2008; Gallet et al. 2008; Yan and Lin 2008). Furthermore, HSPG effects appear attributable to attached sugar chains in some instances (The et al. 1999), and the protein regions of specific glypicans in others (Capurro et al. 2008; Williams et al. 2010; Yan et al. 2010). The vertebrate cell surface proteins Gas1 and Hedgehoginteracting protein (Hhip) have also been shown to bind vertebrate $\mathrm{Hh}$ proteins and modulate Hh signaling positively and negatively, respectively (Chuang and McMahon 1999; Allen et al. 2007; Martinelli and Fan 2007). Hhip transcription, like that of Ptc, is activated by Hh signaling, and these Hh-binding proteins thus act not only to suppress response in cells expressing them, but also to restrict the movement of Hh to more distant cells (Chen et al. 1996; Chuang and McMahon 1999; for review, see Varjosalo and Taipale 2008).

Curiously, no identifiable homologs of Hhip or Gas1 are present in fruit flies, highlighting the absence of a oneto-one correspondence between some components of the vertebrate and fly $\mathrm{Hh}$ pathways. A nonnaturally occurring



Figure 1. Domain organization of proteins in the Hh signaling pathway. Domains for which highresolution structures have been determined are shown in color, and those that are positive or negative regulators of $\mathrm{Hh}$ pathway activity are indicated by $(+)$ or $(-)$, respectively. (Ig) Immunoglobulin; $(\mathrm{Fz})$ Frizzled-like cysteine-rich domain; (EGF) epidermal growth factor; (GFR) glial-derived neurotrophic factor family receptor; (HS) heparan sulfate; (GPI) glycosylphosphatidylinositol. 
modulator of Hh signaling is the anti-HhN monoclonal antibody 5E1, which was raised against rat Shh and crossreacts with both murine and human Shh as well as Ihh (Ericson et al. 1996; Wang et al. 2000). 5E1 blocks Hh signaling and is widely used as a tool to investigate $\mathrm{Hh}$ function in vitro and in vivo (Ericson et al. 1996; Fuse et al. 1999; Pepinsky et al. 2000; Wang et al. 2000). Several other proteins-including Megalin (McCarthy et al. 2002), Vitronectin (Pons and Marti 2000), Perlecan (Park et al. 2003), Scube2 (Tsai et al. 2009), and Shifted (Glise et al. 2005; Gorfinkiel et al. 2005)-have been reported to bind $\mathrm{Hh}$ proteins, but their interactions with $\mathrm{Hh}$ have been less well characterized.

Given the number and complexity of $\mathrm{Hh}$ pathway components at the cell surface, and the intertwined processes of modulating Hh distribution and responsiveness, it has been difficult to develop a molecular view of the nature and consequences of interactions between $\mathrm{Hh}$ proteins and their cell surface partners. This difficulty is due in part to problems isolating functional integral membrane proteins for in vitro analysis, but also to the frequent failure of isolated components of multicomponent systems to faithfully reconstitute function. For example, interactions that are physiologically relevant at the high local concentrations in the cell membrane or when coupled to interactions with additional components may be too weak to detect in vitro /Grasberger et al. 1986). Recent structural, biophysical, and biochemical studies of $\mathrm{Hh}$ proteins complexed with functional fragments of Ihog, Cdo, Boc, Hhip, Ptc, and the monoclonal antibody $5 \mathrm{E} 1$ are beginning to overcome these barriers and add molecular detail to the Hh signaling puzzle (Table 1; McLellan et al. 2006, 2008; Bishop et al. 2009; Bosanac et al. 2009; Kavran et al. 2010; Maun et al. 2010). The molecular underpinnings for previously poorly understood or unconnected aspects of Hh signaling have emerged, as well as startling differences between vertebrate and invertebrate Hh signaling mechanisms.

\section{Hh structure}

All known signaling functions of Hh proteins are mediated by HhN. This domain is highly conserved, with $66 \%$ amino acid sequence identity between human and Drosophila HhN proteins. The crystal structure of ShhN was determined 15 years ago (Hall et al. 1995), and revealed an unanticipated homology with zinc hydrolases (Fig. 2A,B; Dideberg et al. 1982; McCafferty et al. 1997; Bochtler et al. 2004). In ShhN and related zinc hydrolases, a zinc ion is coordinated by two histidines and an aspartate at the base of a large cleft. The fourth ligand of the tetrahedrally coordinated zinc ion is usually a water molecule, which forms a hydrogen bond to a glutamate believed to act as a general base to deprotonate the water for nucleophilic attack of substrates (Fig. 2B). An intact zinc site is conserved in all known $\mathrm{Hh}$ proteins except Drosophila $\mathrm{Hh}$, in which three of the four key zinc site residues are not conserved. Despite initial excitement that an intrinsic hydrolytic activity might contribute to $\mathrm{Hh}$ function, subsequent mutagenesis studies have largely ruled out this possibility (Day et al. 1999; Fuse et al. 1999). The zinc does play an important structural and functional role, however, as loss of zinc or mutations in the zinc site decrease $\mathrm{Hh}$ stability and signaling (Day et al. 1999; Fuse et al. 1999). The same structural features, including a crucial role for zinc, were described recently for human Dhh and Thh (Bishop et al. 2009; Kavran et al. 2010).

The structure of HhC, which mediates self-cleavage of $\mathrm{Hh}$ and attachment of cholesterol to $\mathrm{HhN}$, revealed homology between $\mathrm{HhC}$ and the intein region of selfsplicing proteins (Fig. 2C; Duan et al. 1997; Hall et al. 1997; Klabunde et al. 1998). In contrast to $\mathrm{HhN}$, which shares structural homology but apparently not catalytic activity with zinc hydrolases, HhC shares structural and mechanistic features with the intein regions of selfsplicing proteins, small regions of proteins capable of excising themselves from a larger protein host (for review,

Table 1. Hh-containing crystal structures in the Protein Data Bank

\begin{tabular}{|c|c|c|c|}
\hline Structure & Resolution & PDB code & Reference \\
\hline Murine ShhN, no $\mathrm{Ca}^{2+}$ & $1.7 \AA$ & $1 \mathrm{VHH}$ & Hall et al. 1995 \\
\hline Drosophila HhC & $1.9 \AA$ & $1 \mathrm{AT} 0$ & Hall et al. 1997 \\
\hline Human ShhN & $1.84 \AA$ & $3 \mathrm{M} 1 \mathrm{~N}$ & Pepinsky et al. 2000 \\
\hline Drosophila HhN:IhogFn12 & $2.2 \AA$ & 2IBG & McLellan et al. 2006 \\
\hline Murine ShhN:CdoFn3 & $1.7 \AA$ & $3 \mathrm{D} 1 \mathrm{M}$ & McLellan et al. 2008 \\
\hline Human ShhN:Hhip $\Delta N$ & $3.0 \AA$ & 3HO5 & Bosanac et al. 2009 \\
\hline Human DhhN, no $\mathrm{Ca}^{2+}$ & $1.85 \AA$ & 2WFQ & Bishop et al. 2009 \\
\hline Human $\mathrm{DhhN}, \mathrm{Ca}^{2+}$ & $1.95 \AA$ & $2 \mathrm{WFR}$ & Bishop et al. 2009 \\
\hline Murine ShhN:Hhip $\Delta \mathrm{N}, \mathrm{Ca}^{2+}$ & $3.2 \AA$ & 2WFX & Bishop et al. 2009 \\
\hline Human DhhN:Hhip $\Delta \mathrm{N}$, no $\mathrm{Ca}^{2+}$ & $2.6 \AA$ & 2WG3 & Bishop et al. 2009 \\
\hline Murine ShhN:Hhip $\Delta \mathrm{N}$, no $\mathrm{Ca}^{2+}$ & $3.15 \AA$ & 2WG4 & Bishop et al. 2009 \\
\hline ShhN:5E1 Fab & $1.83 \AA$ & $3 M X W$ & Maun et al. 2010 \\
\hline Human IhhN:CdoFn3 & $1.6 \AA$ & $3 \mathrm{~N} 1 \mathrm{~F}$ & Kavran et al. 2010 \\
\hline Human DhhN:BocFn3 & $1.9 \AA$ & $3 \mathrm{~N} 1 \mathrm{G}$ & Kavran et al. 2010 \\
\hline Human IhhN:BocFn3 & $1.7 \AA$ & $3 \mathrm{~N} 1 \mathrm{M}$ & Kavran et al. 2010 \\
\hline IhhN & $2.55 \AA$ & $3 \mathrm{~N} 1 \mathrm{O}$ & Kavran et al. 2010 \\
\hline IhhN:BocFn3 & $2.7 \AA$ & $3 \mathrm{~N} 1 \mathrm{P}$ & Kavran et al. 2010 \\
\hline DhhN:CdoFn3 & $2.9 \AA$ & $3 N 1 Q$ & Kavran et al. 2010 \\
\hline Murine $\mathrm{ShhN}, \mathrm{Ca}^{2+}$ & $2.1 \AA$ & $3 N 1 R$ & Kavran et al. 2010 \\
\hline
\end{tabular}






B



DhhN
DDept
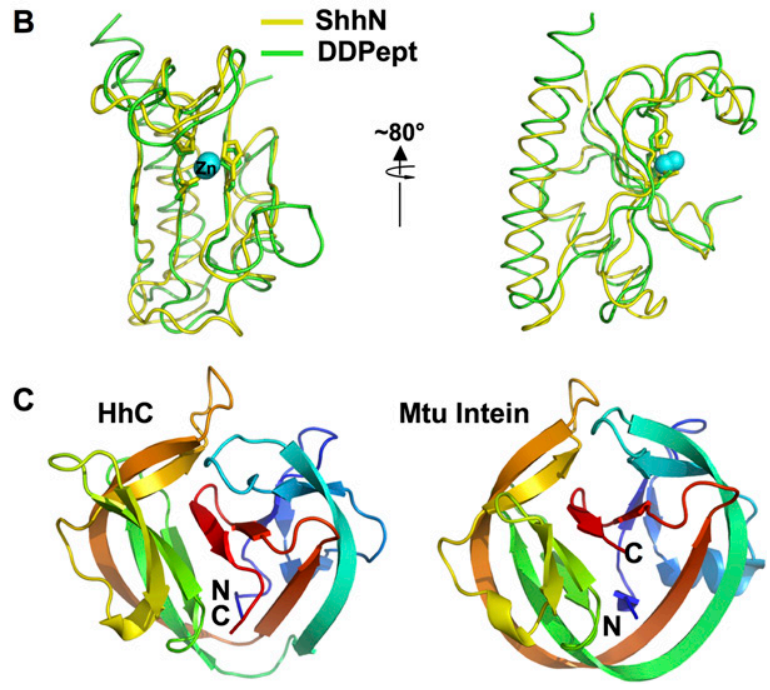

Figure 2. ShhN and HhC. (A) Ribbon diagrams of the $\mathrm{N}$-terminal signaling domain of Sonic hedgehog is shown with zinc-coordinating residues colored in light blue, calciumcoordinating residues colored red, calcium ions colored green, and the zinc ion colored cyan. The view in the right panel is rotated $\sim 80^{\circ}$ about a vertical axis and $\sim 30^{\circ}$ about a horizontal axis relative to the view shown in the left panel. The side chain of the zinc-coordinating aspartate (D148) has been removed in the right panel to show the zinc-binding cleft more clearly. $(B)$ Near-orthogonal views of a superposition of $\alpha$ carbon traces of the core structural elements of ShhN (yellow) and D-Ala-D-Alacarboxypeptidase (green) are shown. The side chains of zinccoordinating residues are shown as sticks, and the zinc ions are shown as cyan spheres. (C) Ribbon diagrams of the HhC (left) and Mtu intein (right) (Hiraga et al. 2009) structures are shown. The ribbons are colored in a rainbow color gradient from blue ( $\mathrm{N}$ terminus) to red ( $\mathrm{C}$ terminus). All structure figures were made using PyMol (http://www.pymol.org).

see Perler 1998). Both HhC and inteins mediate cleavage reactions that proceed via intramolecular ester/thioester intermediates and involve selection of a second nucleophile to attack the ester/thioester. For self-splicing proteins, a side chain just past the C-terminal boundary of the intein provides the second nucleophile; in the case of $\mathrm{HhC}$, the second nucleophile is cholesterol, which becomes attached covalently to $\mathrm{HhN}$ in the process (Perler 1998; Mann and Beachy 2004).

\section{Hh and Thog}

Despite the relatively rapid appearance of ShhN and HhC crystal structures following isolation of the hh gene, a decade passed before complexes of Hh proteins and binding partners began to be characterized structurally and biophysically. This hiatus arose for several reasons, including difficulties purifying active forms of membrane proteins and incomplete identification of key pathway components and cofactors. For example, Ihog and Boi were not identified in early genetic screens for Hh pathway components, presumably owing to their functional redundancy. It was not until a genetic screen was carried out in a cell line that fortuitously lacked Boi that Thog was identified as a component of Hh signaling (Lum et al. 2003). Furthermore, Ihog and its homologs are multidomain proteins with the potential for interdomain flexibility, and successful structural studies required identification of compact, binding-competent subdomains before crystallization trials were successful (Yao et al. 2006).

Pull-down experiments indicated an interaction between $\mathrm{dHhN}$ from conditioned medium and the first FNIII domains of Ihog (IhogFn1) and Boi (Yao et al. 2006), but purified $\mathrm{dHhN}$ and an Ihog fragments encompassing both FNIII domains (IhogFn12) failed to interact in vitro. Only when heparin was present could a stable complex between $\mathrm{dHhN}$ and ThogFn12 be formed and purified using size exclusion chromatography (McLellan et al. 2006). Analytical ultracentrifugation (AUC) and isothermal titration calorimetry (ITC) measurements showed that, in the presence of heparin decasaccharide, (1) dHhN and IhogFn 12 form a 2:2 complex, (2) $\mathrm{dHhN}$ and IhogFn12 interact with low micromolar affinity, (3) IhogFn12 dimerizes with a dissociation constant of $\sim 60 \mu \mathrm{M}$, and (4) little or no cooperativity exists between IhogFn12 dimerization and $\mathrm{dHhN}$ : IhogFn12 interactions (Table 2; McLellan et al. 2006).

The heparin-dependent complex of $\mathrm{dHhN}$ and IhogFn 12 crystallized, and its structure was determined at $2.4 \AA$ resolution (McLellan et al. 2006). A 2:2 dHhN: IhogFn12 complex was observed, and the physiological relevance of the likely $\mathrm{dHhN}$ :IhogFn 12 and IhogFn 12 dimer interfaces was confirmed by mutagenesis. Consistent with the little or no cooperativity observed between $\mathrm{dHhN}$ :IhogFn12 interactions and dimerization of IhogFn12, contacts between the dHhN:IhogFn12 subunits of the 2:2 dimer are mediated entirely by IhogFn 12 , and no significant conformational changes in either $\mathrm{dHhN}$ or IhogFn12 are observed relative to uncomplexed structures. These results suggest that the role of Ihog in $\mathrm{Hh}$ signaling is primarily to bind Hh extracellularly rather than to transmit signals into the cell per se, consistent with the ability of an Ihog variant lacking its cytoplasmic domain to provide function (Yao et al. 2006; Zheng et al. 2010). Despite the presence of heparin decasaccharide in the crystallization buffer, heparin was not visualized in the dHhN:IhogFn 12 crystal structure, presumably owing to the high concentrations of phosphate and sulfate ions required for crystallization. Basic regions on $\mathrm{dHhN}$ and IhogFn1 become apposed in the complex, however, and form a continuous basic stripe without directly participating in the dHhN:IhogFnl interface (Fig. 3B). Independent mutation of these basic regions in Ihog and $\mathrm{HhN}$ diminishes the ability of $\mathrm{HhN}$ to bind Thog in the presence of heparin, leading to a model in which heparin 
Table 2. Dissociation constants $\left(K_{d}, n M\right)$ measured for Hh proteins and partners

\begin{tabular}{|c|c|c|c|c|c|c|c|}
\hline & IhogFn $12^{\mathrm{a}}$ & CdoFn3 & BocFn $3^{b}$ & Hhip $^{c}$ & Hhip $\Delta \mathrm{N}^{\mathrm{c}}$ & Heparin $^{\mathrm{d}}$ & $5 \mathrm{E} 1^{\mathrm{e}}$ \\
\hline ShhN, $\mathrm{Ca}^{2+}$ & - & $1300^{\mathrm{a}}$ & 4300 & 5.8 & 14.0 & - & 0.31 \\
\hline ShhN, no $\mathrm{Ca}^{2+}$ & - & $\mathrm{nd}^{\mathrm{a}}$ & - & 111.5 & 73.9 & 67 & 4.8 \\
\hline $\mathrm{IhhN}, \mathrm{Ca}^{2+}$ & - & $2700^{a}$ & 6600 & - & - & - & 0.29 \\
\hline DhhN, $\mathrm{Ca}^{2+}$ & - & $740^{\mathrm{b}}$ & 520 & 3.0 & 8.7 & - & 1.71 \\
\hline $\mathrm{DhhN}^{\prime}$ no $\mathrm{Ca}^{2+}$ & - & - & - & 202.9 & 384 & - & - \\
\hline Drosophila $\mathrm{HhN}$ & 2600 & - & - & - & - & 47,700 & - \\
\hline
\end{tabular}

(nd) Not detectable.

${ }^{\text {a }}$ Determined by ITC from McLellan et al. (2008).

${ }^{\mathrm{b}}$ Determined by ITC from Kavran et al. (2010).

${ }^{\mathrm{c}}$ Determined by surface plasmon resonance from Bishop et al. (2009).

${ }^{\mathrm{d}}$ Determined by surface plasmon resonance from Zhang et al. (2007).

${ }^{\mathrm{e}}$ Determined by biolayer inferometry in the presence of $\mathrm{Zn}^{2+}$ from Maun et al. (2010).

promotes $\mathrm{dHhN}$ :Ihog by binding this contiguous basic stripe and spanning both molecules in the complex. This "scotch tape" mechanism is similar to that observed for heparin-dependent complexes of fibroblast growth factor and its receptor (Plotnikov et al. 1999), and establishes a molecular mechanism by which loss of heparan sulfate affects response to the Hh signal (McLellan et al. 2006).

\section{Hh and Cdo}

The closest vertebrate homologs of Ihog are Cdo and Boc, and both Cdo and Boc bind vertebrate Hh proteins and positively regulate $\mathrm{Hh}$ signaling (Tenzen et al. 2006; Yao et al. 2006). Cdo and Boc each contain an additional FNIII repeat relative to Ihog and Boi (Fig. 1B), but sequence conservation clearly indicates that the second and third FNIII repeats of Cdo/Boc (Fn2 and Fn3) are homologous to the two Ihog/Boi FNIII repeats (Fn1 and Fn2, respectively) (Kang et al. 2002). Curiously, although orthologous repeats in Ihog (IhogFn1) and Cdo (CdoFn2) bind heparin (Zhang et al. 2007), the Hh-binding FNIII repeats in Cdo and Boc identified by pull-down experiments (CdoFn3 and BocFn3) are not orthologous to the Hh-binding FNIII repeat in Ihog (IhogFn1) (Tenzen et al. 2006; Yao et al. 2006). Reminiscent of dHhN and Ihog, ShhN and CdoFn3 in purified form failed to interact appreciably in vitro. In this case, however, addition of heparin did not promote ShhN/CdoFn3 interactions, and a search for serum components that might do so-the pull-down experiments were carried out in the presence of serum-revealed that calcium ions promote ShhN binding to CdoFn3 in vitro (McLellan et al. 2008). AUC and ITC measurements demonstrate that, in the presence of calcium, ShhN forms a 1:1 complex with CdoFn3 that has a dissociation constant of $\sim 1.3 \mu \mathrm{M}$ (Table 2; McLellan et al. 2008).

A $1.7 \AA$ crystal structure of the ShhN:CdoFn3 complex revealed a previously unappreciated binuclear calcium-binding site on ShhN that is buried at the CdoFn3 interface (Fig. 4; McLellan et al. 2008). The two calcium ions are coordinated by six acidic side chains from ShhN but no atoms from CdoFn3. This calcium site rationalizes the calcium dependence of ShhN:CdoFn3 interactions and is conserved in at least one Hh homolog from all species for which Hh sequences are available. The affinity of this site for calcium is weak $(>0.1 \mathrm{mM})$, which explains the failure to detect ions at this site in earlier studies of ShhN (Hall et al. 1995; Pepinsky et al. 2000). The millimolar concentration of calcium ion in the extracellular milieu and the ability of $1 \mathrm{mM}$ calcium to support ShhN:CdoFn3 binding suggests that this site is likely to be constitutively occupied on the cell surface, although transport to low-calcium or low-pH environments would likely disrupt any calcium-dependent interactions (Brown and MacLeod 2001; McLellan et al. 2008; Kavran et al. 2010). Recent structural and biophysical studies show that this calcium-dependent binding mode is conserved between CdoFn 3 and BocFn3 and each of ShhN, IhhN, and DhhN, and CdoFn3 and BocFn3 (Kavran et al. 2010).

Binding experiments in the presence of the calcium chelator EGTA and with ShhN variants bearing mutations in calcium-coordinating residues indicate that the calcium site contributes to interactions between ShhN and Hhip, Ptc, and Gas1, as well as Cdo and Boc, although the decreases in binding to these partners are not as complete as observed for Cdo/Boc (McLellan et al. 2008; Bishop et al. 2009; Kavran et al. 2010). A missense mutation in Shh that causes holoprosencephaly in humans (D88V) maps to this calcium-binding site (Muenke and Beachy 2001), and introduction of this mutation into ShhN abolishes binding to Cdo and decreases binding to Hhip, Gas1, and Ptc (McLellan et al. 2008). Five missense mutations in Ihh (E95K, E95G, D100N, D100E, and E131K) that cause brachydactyly type A1 (BDA1) map to calcium-coordinating residues (Gao et al. 2001), and introduction of subsets of these mutations in Ihh or their equivalents in Shh eliminates binding to Cdo and decreases binding to Hhip and Ptc (Maity et al. 2005; McLellan et al. 2008). As Cdo and Gas1 are positive regulators of Hh signaling and Ptc and Hhip are negative regulators, the effects of mutations that affect interactions between $\mathrm{Hh}$ proteins and multiple partners can be complex. For example, the D88V substitution in Shh produces a loss-of-function phenotype (Muenke and Beachy 2001), but the BDA1 mutations in Ihh act in a dominant, gain-offunction manner (Gao et al. 2001, 2009). The latter observation suggests that loss of Thh inhibition by Hhip is more responsible for the BDAl phenotype than decreased interactions with $\mathrm{Ptc}$ and $\mathrm{Cdo}$; disruption of interactions with Hhip appear to increase the range of 

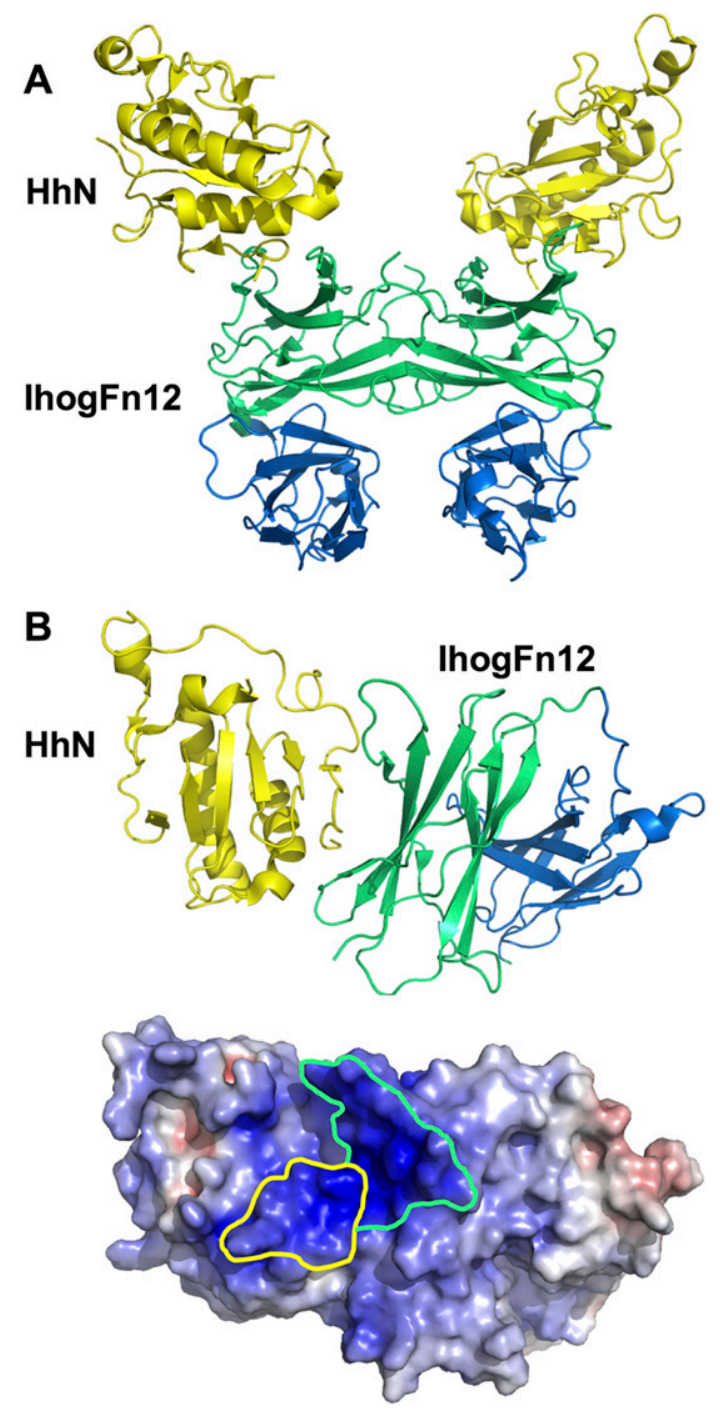

Figure 3. HhN:IhogFn12 complex. (A) A ribbon diagram of the 2:2 HhN:IhogFn12 heterotetramer is shown. HhN is colored yellow, the first FNIII domain of IhogFn 12 is colored green, and the second FNIII domain of IhogFn2 is colored blue. (B, top) A single $\mathrm{HhN}$ :IhogFn12 complex is shown with $\mathrm{HhN}$ oriented similarly to the orientation of ShhN in the left panel of Figures $2 \mathrm{~A}$ and 8. (Bottom) The electrostatic surface potential of the HhN:IhogFn12 complex in the same orientation as in the top panel is shown. A basic region that spans the HhN:IhogFn12 interface is outlined in yellow (portion contributed by $\mathrm{HhN}$ ) and green (portion contributed by IhogFn12). Blue represents regions of positive charge, and red represents regions of negative charge. The scale is $\pm 10 \mathrm{kT} / \mathrm{e}$.

the Ihh signal to regions where even a signal of reduced potency causes a relative increase in Hh pathway activity (Gao et al. 2009).

\section{Ihog and Cdo binding modes are different}

Consistent with the puzzling difference in domain-binding sites observed in pull-down experiments, the $\mathrm{dHhN}$ : IhogFn12 and ShhN:CdoFn3 crystal structures revealed completely different binding modes between these other- wise homologous ligand/coreceptor pairs (Fig. 5). The primary contacts with Hh are formed by nonorthologous FNIII domains of Ihog (IhogFn1) and Cdo (CdoFn3), and the Hh surfaces used to interact with Ihog and Cdo are essentially nonoverlapping (Fig. 5). Extensive mutagenesis studies validate the different binding modes both in vitro and in cell-based assays, and the different binding modes are consistent with the different cofactor dependencies-heparin in the case of $\mathrm{dHhN}$ :Ihog, and calcium in the case of ShhN:Cdo. Furthermore, alteration of four residues in ShhN to their counterparts in $\mathrm{dHhN}$ confers submicromolar Thog binding to ShhN and dramatically improves the ability of Shh to signal in Drosophila imaginal discs (McLellan et al. 2008).

How did such different binding modes arise in a developmentally critical ligand/coreceptor pair? Several possibilities exist, including evolution of Ihog/Cdo binding independently in different clades, divergence of binding modes after duplication of the $h h$ gene, transition through a bimodal binding intermediate, a heightened capacity to evolve new binding modes owing to $\mathrm{Hh}$ multivalence and membrane association, or some combination of these mechanisms (McLellan et al. 2008). All mammalian Hh proteins bind Cdo and Boc by the same mode, however, indicating that, if different binding modes evolved after $h h$ duplication, the Thog-like binding mode was subsequently lost in mammals (Kavran et al. 2010). Also of note is that extensive sequence homology searches fail to identify clear Ihog/Cdo homologs in nonvertebrate and noninsect species. If or how Hh binds to Ihog/Cdo homologs in intervening clades is thus unknown, and convergent evolutionary schemes cannot be ruled out.

\section{Hh and Hhip}

Hhip contains a predicted N-terminal Frizzled-like cysteine-rich domain followed by a $\beta$-propeller region, two epidermal growth factor (EGF) repeats, and a 22 -aminoacid C-terminal hydrophobic region that attaches Hhip to the cell membrane (Chuang and McMahon 1999; Bishop et al. 2009; Bosanac et al. 2009). Hhip binds Shh, Ihh, and
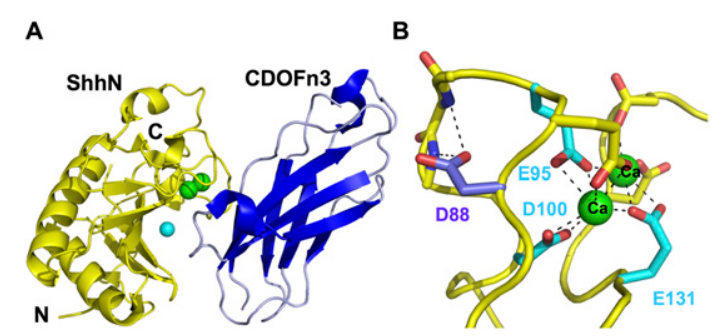

Figure 4. ShhN:CdoFn3. (A) Ribbon diagram of the ShhN: CdoFn3 complex. ShhN is shown in yellow, and CdoFn3 is shown in blue. Calcium ions are shown as green spheres, and the zinc ion is shown as a cyan sphere. (B) A closeup view of the calciumcoordinating region of murine ShhN is shown. The side chain of D88, which is homologous to D89 in human ShhN and the site of a holoprosencephaly-causing mutation in human $\mathrm{ShhN}$, is colored purple. The side chains of E95, D100, and E131, which are homologous to sites of BDA1-causing mutations in human IhhN, are colored cyan, and the calcium ions are shown as green spheres. 


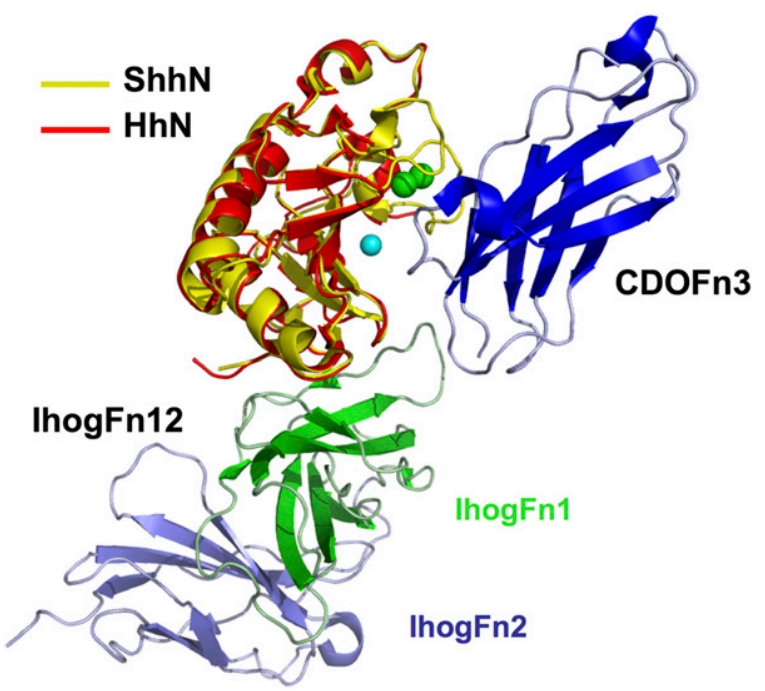

Figure 5. Different HhN-binding modes of Ihog and Cdo. Ribbon diagrams of the ShhN:CdoFn3 and HhN:IhogFn12 complexes are shown following superposition of $\mathrm{ShhN}$ and $\mathrm{HhN}$. ShhN is colored yellow, HhN is red, CdoFn3 is blue, and IhogFn 12 is green/light blue. The ShhN-bound calcium and zinc ions are shown as green and cyan spheres, respectively.

Dhh with low nanomolar affinity, and functions as an inhibitor of Hh signaling (Chuang and McMahon 1999; Chuang et al. 2003). Biophysical and cell-based binding assays demonstrate that the Hhip $\beta$-propeller region is the minimal Hh interaction domain (Bishop et al. 2009; Bosanac et al. 2009). Crystal structures of this $\beta$-propeller region followed by the two EGF repeats $($ Hhip $\Delta \mathrm{N})$, both alone and complexed with $\mathrm{ShhN}$ and $\mathrm{DhhN}$, were determined recently, and show that Hhip $\Delta \mathrm{N}$ adopts a lollipop-like structure with the $\beta$-propeller disc attached to an EGF repeat stem (Fig. 6A; Bishop et al. 2009; Bosanac et al. 2009). Hhip contacts Hh proteins through loops extending from different blades of the $\beta$-propeller, the most prominent of which extends from blade 3 (residues 376388 ) into the zinc-containing cleft on $\mathrm{HhN}$ proteins. Mutagenesis studies suggest that the blade 3 loop, termed the L2 (loop 2) by Bosanac et al. (2009) and BL1 (binding loop 1) by Bishop et al. (2009), is the most energetically important of the interacting loops. Of particular note, the side chain of Asp 383 from Hhip directly coordinates the Hh-bound zinc ion, displacing the water molecule observed to coordinate zinc at that site in structures of ShhN alone (Fig. 6B).

A scan of known Hh-binding partners for conserved Hh-binding motifs identified a region in the second large extracellular loop of Ptc with striking similarity to the D383-containing loop of Hhip (Bosanac et al. 2009). Seven of 18 positions, including a D383 homolog, are conserved as hydrophobic, glycine, or acidic in an alignment of the D383-binding loop sequence with this region in Ptc proteins. A Ptc peptide encompassing this region binds weakly to the zinc site in $\mathrm{ShhN}$ and competes for binding with the Hhip D383-containing loop peptide (Bosanac et al. 2009). These results implicate this region of Ptc in binding Hh ligands, and demonstrate that Hhip likely inhibits Hh signaling by competing directly with Ptc for Hh binding. Cdo was also shown to compete with Hhip for Hh binding (McLellan et al. 2008), consistent with the considerable overlap of the Cdo- and Hhip-binding surfaces on HhN (Bishop et al. 2009; Bosanac et al. 2009).
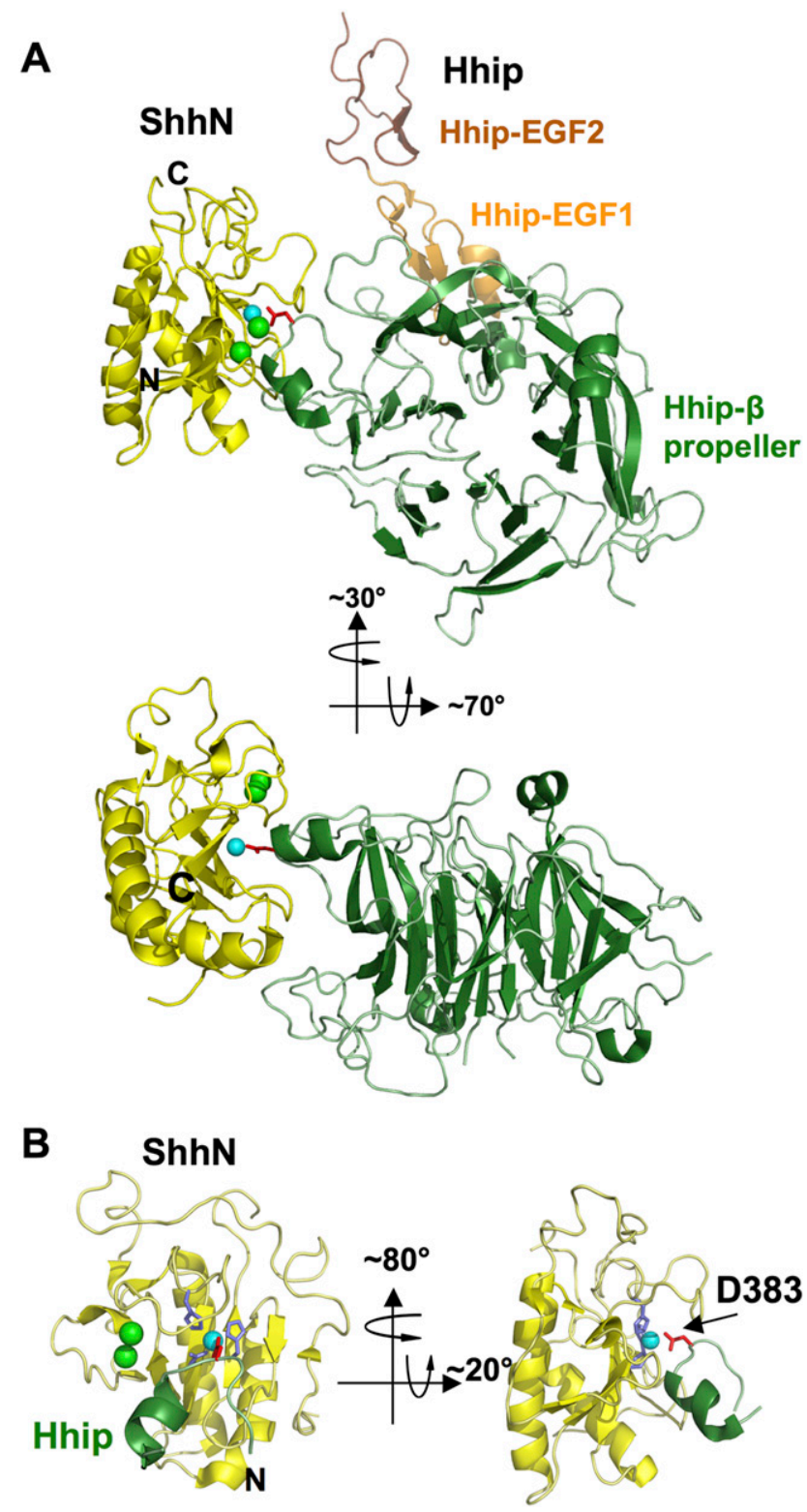

Figure 6. ShhN:Hhip. (A) Ribbon diagrams of ShhN (yellow) and Hhip $\Delta \mathrm{N}$ (the $\beta$-propeller region is colored dark green, the first EGF repeat is shown in orange, and the second EGF repeat is colored brown) are shown in orientations parallel and perpendicular to the plane of the $\beta$-propeller. The side chain of D383 is colored red, calcium ions are colored green, and the zinc ion is colored cyan. In the bottom panel, the EGF repeats have been removed for clarity. (B) Ribbon diagrams of ShhN (yellow) in orientations similar to those shown in Figure 2A are shown with the blade 3 loop of Hhip (dark green). Zinc-coordinating side chains are colored blue, the Hhip D383 side chain is colored red, the zinc ion is shown as a cyan sphere, and the calcium ions are shown as green spheres. The calcium ions have been removed from the right panel for clarity. 
Calcium is important for optimal interactions between $\mathrm{HhN}$ and Hhip, and the affinity of Hhip for HhN drops between fivefold and 70-fold in the absence of calcium, depending on the length of Hhip or the homolog of $\mathrm{HhN}$ that is examined (McLellan et al. 2008; Bishop et al. 2009). Curiously, the Hhip/HhN interface does not overlap with the calcium-binding site on HhN (Bishop et al. 2009; Bosanac et al. 2009). This calcium-binding site is adjacent to the Hhip-binding site, however, and undergoes considerable ordering and charge neutralization when calcium is bound (McLellan et al. 2008; Bishop et al. 2009; Bosanac et al. 2009), which likely underlies its influence on Hhip binding.

\section{Hh and 5E1}

$5 \mathrm{E} 1$ is a monoclonal anti-ShhN antibody that blocks Hh signaling (Ericson et al. 1996), and mutation of ShhN surface residues that disrupt binding to Ptc also disrupt binding to $5 \mathrm{E} 1$ in a manner suggestive of a nonlinear epitope for 5E1 (Fuse et al. 1999). The recent structure of a complex of ShhN and the 5E1 Fab revealed that 5E1 binds ShhN across the zinc-containing cleft at a surface that largely overlaps with the Hhip-binding site (Fig. 7; Maun et al. 2010). 5E1 competes with a peptide derived from the Hhip D383-containing loop for binding to Shh, which highlights the functional dependence of both Hhip and 5E1 on the zinc cleft (Maun et al. 2010). Despite the similarity of the 5E1 and Hhip "footprints" on ShhN (Fig. 8 ), the structural elements used by $5 \mathrm{E} 1$ and Hhip to contact ShhN differ substantially. Unlike Hhip, 5E1 does not project a continuous loop into the Hh zinc cleft. Rather, residues from all six complementarity-determining regions (CDRs) of 5E1 contact ShhN.

Although 5E1 does not directly contact ShhN-bound zinc or calcium ions, 5E1 nonetheless requires $\mathrm{Zn}^{2+}$ and $\mathrm{Ca}^{2+}$ for optimal binding to ShhN. The 5E1 dependence on $\mathrm{Zn}^{2+}$ and $\mathrm{Ca}^{2+}$ is not as profound as the respective dependences of Hhip and Cdo for these ions, however, and likely stems from multiple interactions, including (1) a hydrogen bond between CDR heavy chain $3(\mathrm{H} 3)$ of 5E1 and a water that completes the coordination sphere of the ShhN-bound zinc ion, and (2) van der Waals contacts between a tryptophan from $\mathrm{H} 3$ and residues contributing to the $\mathrm{Ca}^{2+}$-binding loop. The $5 \mathrm{E} 1-\mathrm{ShhN}$ structure further implicates the zinc cleft as being important for $\mathrm{Hh}$

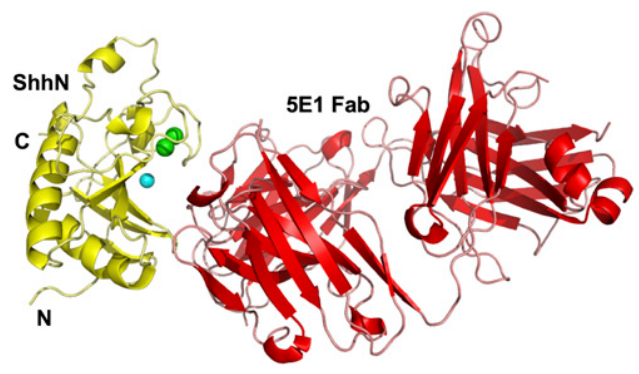

Figure 7. ShhN:5E1 Fab. A ribbon diagram of ShhN (yellow) complexed with the Fab fragment of the 5E1 antibody (red) is shown. Calcium and zinc ions are colored green and cyan, respectively.


Figure 8. HhN-binding surfaces. Molecular surfaces of ShhN or $\mathrm{dHhN}$ are shown with atoms within $4 \AA$ of the indicated binding partner colored blue (CdoFn3), light green (IhogFn12), dark green (Hhip), and red (5E1 Fab). The orientation of each surface is the same as that of the ribbon diagram of ShhN in the top left, in which calcium and zinc ions are shown as green and cyan spheres, respectively, with the exception of the side view of the IhogFn12-binding surface (top right), which is rotated $90^{\circ}$ about a vertical axis relative to the ShhN ribbon. When present, zinc ions are shown as cyan spheres. The calcium ions bound to ShhN are buried and are not visible in surface representations, but their position can be inferred by reference to the ribbon diagram of ShhN (which is at top left).

signaling, and suggests that $5 \mathrm{E} 1$ likely inhibits $\mathrm{Hh}$ signaling by competing directly with Ptc for Shh binding. This model for 5E1 function is consistent with cell-based competition data in which preincubation of Shh with either 5E1 or soluble Hhip prevents binding to Ptc-expressing cells (Bosanac et al. 2009). Thus, while Ptc, Hhip, and $5 \mathrm{E} 1$ are all negative regulators of the Hh pathway, Ptc acts as a repressor of Smo, whereas Hhip and 5E1 sequester Hh from productive interactions with Ptc.

\section{Conclusion}

The involvement of many cell surface factors in regulating Hh signaling has complicated efforts to unravel the nature and consequences of molecular interactions governing activity in the Hh signaling pathway. Added to this complexity is a convolution of $\mathrm{Hh}$ response with $\mathrm{Hh}$ distribution and transport as well as a divergence in the number and function of pathway components in vertebrates and invertebrates. Recent structural and biophysical results characterizing interactions between Hh proteins and binding partners Ihog, Cdo, Boc, Hhip, and the monoclonal antibody 5E1 have begun to clarify this situation. These results build on earlier mutagenesis studies (Day et al. 1999; Fuse et al. 1999), and demonstrate the importance of the zinc-containing cleft and surrounding surfaces in vertebrate $\mathrm{Hh}$ proteins for mediating interactions with key binding partners Ptc, Cdo, Boc, and Hhip as well as the function-blocking antibody 5E1. Although the Ptc-binding site remains to be fully 
characterized, the Ptc-, Hhip-, and 5E1-binding sites on ShhN overlap substantially, and these molecules compete for Hh binding (Fig. 8). The Hhip-binding site on $\mathrm{HhN}$ also overlaps with that of Cdo and Boc, and these molecules also compete for $\mathrm{HhN}$ binding.

Identification of a conserved, binuclear calcium-binding site on ShhN $\sim 12 \AA$ away from the known zincbinding site came as a surprise, but served to rationalize many earlier observations. Mutations in calcium-coordinating residues affect interactions between Hh proteins and Cdo, Boc, Ptc, Hhip, and Gas1, and lead to holoprosencephaly and BDAl in humans when present in Shh and Ihh, respectively. As mutations at this site affect interactions with multiple partners, including both positive and negative regulators of Hh signaling, their phenotypic effects can be a complex mix of gain and loss of function. Thus, for example, although BDA1 mutations somewhat reduce Ptc binding and the signaling potency of the Ihh ligand, they more severely reduce inhibitory Ihh/Hhip interactions and thus increase the range of Ihh signaling, leading to the observed dominant genetic effect. Although the affinity of $\mathrm{HhN}$ proteins for $\mathrm{Ca}^{2+}$ is weak (McLellan et al. 2008), the millimolar concentrations of extracellular $\mathrm{Ca}^{2+}$ suggest that this site is constitutively occupied and unlikely to play a regulatory role outside the cell. Coordination of the two bound calcium ions with six conserved acidic residues implies that calcium binding and hence interactions with multiple partners will decrease in low-pH or low-calcium conditions (Kavran et al. 2010). Decreased interactions in the low-pH environment of the endosome, for example, may allow release and recycling of endocytosed $\mathrm{HhN}$ or its binding partners.

Another surprise to emerge from structural and biophysical studies of Hh was the completely different binding modes observed for vertebrate and invertebrate Hh proteins and their homologous coreceptors, Cdo and Ihog. Although both Ihog and Cdo appear to be positive regulators of Hh signaling, the different binding modes may reflect different roles in $\mathrm{Hh}$ signaling. There is consensus that Ihog and dPtc synergize when binding to $\mathrm{dHhN}$ (Zheng et al. 2010), but the situation for Cdo is less clear, as one report indicates synergy between Cdo and Ptc for $\mathrm{HhN}$ binding, whereas a second notes competition (Martinelli and Fan 2007; McLellan et al. 2008). In any event, the binding of Ihog and Cdo at different sites on cognate $\mathrm{HhN}$ proteins and their reliance on different essential cofactors (heparin in the case of Ihog, and calcium in the case of Cdo) illustrate that distinct regulatory mechanisms govern vertebrate and invertebrate $\mathrm{Hh}$ signaling. In light of this observation, it is interesting to note that the vertebrate Boc protein plays a role in Shh-mediated axonal guidance via a nontranscriptional mechanism /Okada et al. 2006; Yam et al. 2009); whether Drosophila Ihog or Boi has such activity remains to be seen. The example of Ihog and its homologs cautions against assuming conserved mechanisms or modes of interaction for vertebrate and invertebrate homologs of other Hh pathway components, and it will be intriguing to learn from future studies whether or how glypicans function differently in vertebrate and invertebrate Hh signaling, or if fundamental differences exist in how vertebrate and invertebrate Ptc proteins interact with cognate Hh proteins.

When initially discovered, the zinc site in HhN proteins and its homology with active sites of zinc hydrolases excited much interest by implying that a hydrolytic activity might be a feature of Hh function. As subsequent mutagenesis studies discounted this possibility (Day et al. 1999; Fuse et al. 1999), the functional role of the zinc site drew less attention. The discovery that Hhip binds $\mathrm{HhN}$ by occupying the zinc cleft and that an aspartate residue from Hhip directly coordinates the HhN-bound zinc ion established a functionally important role for the zinc site in Hh proteins. Sequence homology arguments and peptide-binding studies make a strong case that a loop on Ptc binds $\mathrm{HhN}$ in a manner similar to the HhN-Hhip interaction (Bosanac et al. 2009), consistent with earlier mutagenesis studies that also map Ptc binding near this region on ShhN (Fuse et al. 1999; Pepinsky et al. 2000). The absence of an intact zinc site in $\mathrm{dHhN}$ remains curious, but perhaps suggests that it is the large substrate-binding cleft rather than the zinc ion itself that is most essential for mediating HhN-Ptc interactions. Indeed, mutation of Hhip D383 to alanine does not completely abolish binding between Hhip and ShhN (Bishop et al. 2009; Bosanac et al. 2009), and several mutations in the IhhN zinc cleft have been identified recently in BDA1 patients (Liu et al. 2006; Byrnes et al. 2009).

The existence of multiple cofactors capable of modulating responses to Hh engenders the capacity to fine-tune the range and strength of $\mathrm{Hh}$ signal responses in various tissues. The binding of both positive and negative regulators to contiguous or overlapping surfaces on Hh proteins raises several questions, however. How, for example, can binding of a positive cofactor, such as Cdo, augment response to Hh signaling and at the same time compete with Ptc for binding to ShhN (McLellan et al. 2008)? One possibility is that Hh ligands in vivo are likely to be multivalent, so that binding of one factor is not necessarily exclusive of Ptc binding to another ligand within a multivalent ligand complex. The requirement for lipid modification for normal in vivo activity is consistent with this type of mechanism /Chamoun et al. 2001; Zeng et al. 2001; Chen et al. 2004; Panakova et al. 2005), as multivalency depends on lipid modification (Chen et al. 2004). If binding of a multivalent ligand to multiple competing partners can have a positive effect on signaling, the question then arises of why Hhip negatively affects signaling. Our present studies do not resolve this issue, but it is possible that the $>100$-fold tighter binding of ShhN to Hhip relative to Cdo permits physiological levels of Hhip to fully occupy ligand sites in a multivalent complex. The lower affinities of other positive cofactors may result in occupancy of only a fraction of ligand sites, and thus actually function to increase the concentration of ligands near the membrane that are available for interacting with Ptc. The determining factor for the effect of a particular protein thus would be whether its binding 
affinity and physiological concentration range enable it to fully or only partially engage the $\mathrm{HhN}$ proteins within multivalent complexes. This hypothesis could be tested by manipulating affinities and expression levels of specific $\mathrm{Hh}$ pathway components. Thus, for example, variant Cdo/Boc or Gas1 proteins that bind Hh more tightly may become inhibitors of Hh signaling, and Hhip variants that bind Hh less tightly may promote Hh signaling. Physical and biochemical studies for the most part have yet to address the effects of ligand multivalency, and this aspect of $\mathrm{Hh}$ delivery and signaling is clearly ripe for future exploration.

\section{Acknowledgments}

We thank the members of their laboratories for their efforts contributing much of the work described in this review. We also thank HHMI (P.A.B.), NIH HD055545 (D.J.L.), and the Wellcome Trust (C.S.) for funding.

\section{References}

Alcedo J, Ayzenzon M, Von Ohlen T, Noll M, Hooper JE. 1996. The Drosophila smoothened gene encodes a seven-pass membrane protein, a putative receptor for the hedgehog signal. Cell 86: 221-232.

Allen BL, Tenzen T, McMahon AP. 2007. The Hedgehog-binding proteins Gas1 and Cdo cooperate to positively regulate Shh signaling during mouse development. Genes Dev 21: 1244-1257.

Amanai K, Jiang J. 2001. Distinct roles of Central missing and Dispatched in sending the Hedgehog signal. Development 128: $5119-5127$.

Beckett K, Franch-Marro X, Vincent JP. 2008. Glypican-mediated endocytosis of Hedgehog has opposite effects in flies and mice. Trends Cell Biol 18: 360-363.

Bishop B, Aricescu AR, Harlos K, O'Callaghan CA, Jones EY, Siebold C. 2009. Structural insights into hedgehog ligand sequestration by the human hedgehog-interacting protein HHIP. Nat Struct Mol Biol 16: 698-703.

Bitgood MJ, Shen L, McMahon AP. 1996. Sertoli cell signaling by Desert hedgehog regulates the male germline. Curr Biol 6: 298-304.

Bochtler M, Odintsov SG, Marcyjaniak M, Sabala I. 2004. Similar active sites in lysostaphins and D-Ala-D-Ala metallopeptidases. Protein Sci 13: 854-861.

Bosanac I, Maun HR, Scales SI, Wen X, Lingel A, Bazan JF, de Sauvage FJ, Hymowitz SG, Lazarus RA. 2009. The structure of SHH in complex with HHIP reveals a recognition role for the Shh pseudo active site in signaling. Nat Struct Mol Biol 16: 691-697.

Brown EM, MacLeod RJ. 2001. Extracellular calcium sensing and extracellular calcium signaling. Physiol Rev 81: 239-297.

Buglino JA, Resh MD. 2008. Hhat is a palmitoylacyltransferase with specificity for $\mathrm{N}$-palmitoylation of Sonic Hedgehog. J Biol Chem 283: 22076-22088.

Bumcrot DA, Takada R, McMahon AP. 1995. Proteolytic processing yields two secreted forms of sonic hedgehog. Mol Cell Biol 15: 2294-2303.

Burke R, Nellen D, Bellotto M, Hafen E, Senti KA, Dickson BJ, Basler K. 1999. Dispatched, a novel sterol-sensing domain protein dedicated to the release of cholesterol-modified hedgehog from signaling cells. Cell 99: 803-815.

Byrnes AM, Racacho L, Grimsey A, Hudgins L, Kwan AC, Sangalli M, Kidd A, Yaron Y, Lau YL, Nikkel SM, et al. 2009. Brachydactyly A-1 mutations restricted to the central region of the N-terminal active fragment of Indian Hedgehog. Eur J Hum Genet 17: 1112-1120.
Capurro MI, Xu P, Shi W, Li F, Jia A, Filmus J. 2008. Glypican-3 inhibits Hedgehog signaling during development by competing with patched for Hedgehog binding. Dev Cell 14: 700-711.

Chamoun Z, Mann RK, Nellen D, von Kessler DP, Bellotto M, Beachy PA, Basler K. 2001. Skinny hedgehog, an acyltransferase required for palmitoylation and activity of the hedgehog signal. Science 293: 2080-2084.

Chang DT, Lopez A, von Kessler DP, Chiang C, Simandl BK, Zhao R, Seldin MF, Fallon JF, Beachy PA. 1994. Products, genetic linkage and limb patterning activity of a murine hedgehog gene. Development 120: 3339-3353.

Chen X, Levkowitz G, Tzahar E, Karunagaran D, Lavi S, BenBaruch N, Leitner O, Ratzkin BJ, Bacus SS, Yarden Y. 1996. An immunological approach reveals biological differences between the two NDF/heregulin receptors, ErbB-3 and ErbB-4. J Biol Chem 271: 7620-7629.

Chen MH, Li YJ, Kawakami T, Xu SM, Chuang PT. 2004. Palmitoylation is required for the production of a soluble multimeric Hedgehog protein complex and long-range signaling in vertebrates. Genes Dev 18: 641-659.

Chiang C, Litingtung Y, Lee E, Young KE, Corden JL, Westphal H, Beachy PA. 1996. Cyclopia and defective axial patterning in mice lacking Sonic hedgehog gene function. Nature 383: 407-413.

Chuang PT, McMahon AP. 1999. Vertebrate Hedgehog signalling modulated by induction of a Hedgehog-binding protein. Nature 397: 617-621.

Chuang PT, Kawcak T, McMahon AP. 2003. Feedback control of mammalian Hedgehog signaling by the Hedgehog-binding protein, Hip1, modulates Fgf signaling during branching morphogenesis of the lung. Genes Dev 17: 342-347.

Cole F, Krauss RS. 2003. Microform holoprosencephaly in mice that lack the Ig superfamily member Cdon. Curr Biol 13: 411-415.

Corbit KC, Aanstad P, Singla V, Norman AR, Stainier DY, Reiter JF. 2005. Vertebrate Smoothened functions at the primary cilium. Nature 437: 1018-1021.

Day ES, Wen D, Garber EA, Hong J, Avedissian LS, Rayhorn P, Shen W, Zeng C, Bailey VR, Reilly JO, et al. 1999. Zincdependent structural stability of human Sonic hedgehog. Biochemistry 38: 14868-14880.

Denef N, Neubuser D, Perez L, Cohen SM. 2000. Hedgehog induces opposite changes in turnover and subcellular localization of patched and smoothened. Cell 102: 521531.

Desbordes SC, Sanson B. 2003. The glypican Dally-like is required for Hedgehog signalling in the embryonic epidermis of Drosophila. Development 130: 6245-6255.

Dideberg O, Charlier P, Dive G, Joris B, Frere JM, Ghuysen JM. 1982. Structure of a $\mathrm{Zn}^{2+}$-containing D-alanyl-D-alanine-cleaving carboxypeptidase at $2.5 \AA$ resolution. Nature 299: 469-470.

Duan X, Gimble FS, Quiocho FA. 1997. Crystal structure of PISceI, a homing endonuclease with protein splicing activity. Cell 89: 555-564.

Echelard Y, Epstein DJ, St-Jacques B, Shen L, Mohler J, McMahon JA, McMahon AP. 1993. Sonic hedgehog, a member of a family of putative signaling molecules, is implicated in the regulation of CNS polarity. Cell 75: 1417-1430.

Ericson J, Morton S, Kawakami A, Roelink H, Jessell TM. 1996. Two critical periods of Sonic Hedgehog signaling required for the specification of motor neuron identity. Cell 87: 661-673.

Filmus J, Capurro M, Rast J. 2008. Glypicans. Genome Biol 9: 224. doi: $10.1186 / g b-2008-9-5-224$.

Fuse N, Maiti T, Wang B, Porter JA, Hall TM, Leahy DJ, Beachy PA. 1999. Sonic hedgehog protein signals not as a hydrolytic 
enzyme but as an apparent ligand for patched. Proc Natl Acad Sci 96: 10992-10999.

Gallet A, Staccini-Lavenant L, Therond PP. 2008. Cellular trafficking of the glypican Dally-like is required for fullstrength Hedgehog signaling and wingless transcytosis. Dev Cell 14: 712-725.

Gao B, Guo J, She C, Shu A, Yang M, Tan Z, Yang X, Guo S, Feng G, He L. 2001. Mutations in IHH, encoding Indian hedgehog, cause brachydactyly type A-1. Nat Genet 28: 386-388.

Gao B, Hu J, Stricker S, Cheung M, Ma G, Law KF, Witte F, Briscoe J, Mundlos S, He L, et al. 2009. A mutation in Ihh that causes digit abnormalities alters its signalling capacity and range. Nature 458: 1196-1200.

Glise B, Miller CA, Crozatier M, Halbisen MA, Wise S, Olson DJ, Vincent A, Blair SS. 2005. Shifted, the Drosophila ortholog of Wnt inhibitory factor-1, controls the distribution and movement of Hedgehog. Dev Cell 8: 255-266.

Goodrich LV, Johnson RL, Milenkovic L, McMahon JA, Scott MP. 1996. Conservation of the hedgehog/patched signaling pathway from flies to mice: Induction of a mouse patched gene by Hedgehog. Genes Dev 10: 301-312.

Gorfinkiel N, Sierra J, Callejo A, Ibanez C, Guerrero I. 2005. The Drosophila ortholog of the human Wnt inhibitor factor Shifted controls the diffusion of lipid-modified Hedgehog. Dev Cell 8: 241-253.

Grasberger B, Minton AP, DeLisi C, Metzger H. 1986. Interaction between proteins localized in membranes. Proc Natl Acad Sci 83: 6258-6262.

Hall TM, Porter JA, Beachy PA, Leahy DJ. 1995. A potential catalytic site revealed by the $1.7-\AA$ crystal structure of the amino-terminal signalling domain of Sonic hedgehog. Nature 378: 212-216.

Hall TM, Porter JA, Young KE, Koonin EV, Beachy PA, Leahy DJ. 1997. Crystal structure of a Hedgehog autoprocessing domain: Homology between Hedgehog and self-splicing proteins. Cell 91: 85-97.

Han C, Belenkaya TY, Wang B, Lin X. 2004. Drosophila glypicans control the cell-to-cell movement of Hedgehog by a dynamin-independent process. Development 131: 601611.

Hiraga K, Soga I, Dansereau JT, Pereira B, Derbyshire V, Du Z, Wang C, Van Roey P, Belfort G, Belfort M. 2009. Selection and structure of hyperactive inteins: Peripheral changes relayed to the catalytic center. J Mol Biol 393: 1106-1117.

Hooper JE, Scott MP. 1989. The Drosophila patched gene encodes a putative membrane protein required for segmental patterning. Cell 59: 751-765.

Ingham PW, Taylor AM, Nakano Y. 1991. Role of the Drosophila patched gene in positional signaling. Nature 353: 184-187.

Ingham PW, Nystedt S, Nakano Y, Brown W, Stark D, van den Heuvel M, Taylor AM. 2000. Patched represses the Hedgehog signalling pathway by promoting modification of the Smoothened protein. Curr Biol 10: 1315-1318.

Johnson RL, Rothman AL, Xie J, Goodrich LV, Bare JW, Bonifas JM, Quinn AG, Myers RM, Cox DR, Epstein EH Jr, et al. 1996. Human homolog of patched, a candidate gene for the basal cell nevus syndrome. Science 272: 1668-1671.

Kang JS, Mulieri PJ, Hu Y, Taliana L, Krauss RS. 2002. BOC, an Ig superfamily member, associates with $\mathrm{CDO}$ to positively regulate myogenic differentiation. EMBO I 21: 114-124.

Kavran JM, Ward MD, Oladosu OO, Mulepati S, Leahy DJ. 2010. All mammalian Hedgehog proteins interact with CDO and BOC in a conserved manner. I Biol Chem 285: 24584 24590.

Klabunde T, Sharma S, Telenti A, Jacobs WR Jr, Sacchettini JC. 1998. Crystal structure of GyrA intein from Mycobacterium xenopi reveals structural basis of protein splicing. Nat Struct Biol 5: 31-36.

Krauss S, Concordet JP, Ingham PW. 1993. A functionally conserved homolog of the Drosophila segment polarity gene hh is expressed in tissues with polarizing activity in zebrafish embryos. Cell 75: 1431-1444.

Lee JJ, von Kessler DP, Parks S, Beachy PA. 1992. Secretion and localized transcription suggest a role in positional signaling for products of the segmentation gene hedgehog. Cell 71: 33-50.

Lee JJ, Ekker SC, von Kessler DP, Porter JA, Sun BI, Beachy PA. 1994. Autoproteolysis in hedgehog protein biogenesis. Science 266: 1528-1537.

Lee JD, Kraus P, Gaiano N, Nery S, Kohtz J, Fishell G, Loomis CA, Treisman JE. 2001. An acylatable residue of Hedgehog is differentially required in Drosophila and mouse limb development. Dev Biol 233: 122-136.

Liu M, Wang X, Cai Z, Tang Z, Cao K, Liang B, Ren X, Liu JY, Wang QK. 2006. A novel heterozygous mutation in the Indian hedgehog gene $(\mathrm{IHH})$ is associated with brachydactyly type A1 in a Chinese family. J Hum Genet 51: 727-731.

Lum L, Yao S, Mozer B, Rovescalli A, Von Kessler D, Nirenberg M, Beachy PA. 2003. Identification of Hedgehog pathway components by RNAi in Drosophila cultured cells. Science 299: 2039-2045.

Maity T, Fuse N, Beachy PA. 2005. Molecular mechanisms of Sonic hedgehog mutant effects in holoprosencephaly. Proc Natl Acad Sci 102: 17026-17031.

Mann RK, Beachy PA. 2004. Novel lipid modifications of secreted protein signals. Annu Rev Biochem 73: 891-923.

Marigo V, Davey RA, Zuo Y, Cunningham JM, Tabin CJ. 1996. Biochemical evidence that patched is the Hedgehog receptor. Nature 384: 176-179.

Martinelli DC, Fan CM. 2007. Gas1 extends the range of Hedgehog action by facilitating its signaling. Genes Dev 21: 1231-1243.

Maun HR, Wen X, Lingel A, de Sauvage FJ, Lazarus RA, Scales SJ, Hymowitz SG. 2010. The Hedgehog pathway antagonist $5 \mathrm{E} 1$ binds Hedgehog at the pseudo-active site. I Biol Chem 285: 26570-26580.

McCafferty DG, Lessard IA, Walsh CT. 1997. Mutational analysis of potential zinc-binding residues in the active site of the enterococcal D-Ala-D-Ala dipeptidase VanX. Biochemistry 36: 10498-10505.

McCarthy RA, Barth JL, Chintalapudi MR, Knaak C, Argraves WS. 2002. Megalin functions as an endocytic sonic hedgehog receptor. I Biol Chem 277: 25660-25667.

McLellan JS, Yao S, Zheng X, Geisbrecht BV, Ghirlando R, Beachy PA, Leahy DJ. 2006. Structure of a heparin-dependent complex of Hedgehog and Thog. Proc Natl Acad Sci 103: 17208-17213.

McLellan JS, Zheng X, Hauk G, Ghirlando R, Beachy PA, Leahy DJ. 2008. The mode of Hedgehog binding to Ihog homologues is not conserved across different phyla. Nature 455: 979-983.

McMahon AP, Ingham PW, Tabin CJ. 2003. Developmental roles and clinical significance of hedgehog signaling. Curr Top Dev Biol 53: 1-114.

Micchelli CA, The I, Selva E, Mogila V, Perrimon N. 2002. Rasp, a putative transmembrane acyltransferase, is required for Hedgehog signaling. Development 129: 843-851.

Mohler J, Vani K. 1992. Molecular organization and embryonic expression of the hedgehog gene involved in cell-cell communication in segmental patterning of Drosophila. Development 115: 957-971.

Muenke M, Beachy PA. 2001. Holoprosencephaly. In The metabolic and molecular bases of inherited disease (ed. CR Scriver et al.), pp. 6203-6230. McGraw-Hill, New York. 
Nakano Y, Guerrero I, Hidalgo A, Taylor A, Whittle JR, Ingham PW. 1989. A protein with several possible membrane-spanning domains encoded by the Drosophila segment polarity gene patched. Nature 341: 508-513.

Nusslein-Volhard C, Wieschaus E. 1980. Mutations affecting segment number and polarity in Drosophila. Nature 287: 795-801.

Okada A, Charron F, Morin S, Shin DS, Wong K, Fabre PJ, Tessier-Lavigne M, McConnell SK. 2006. Boc is a receptor for sonic hedgehog in the guidance of commissural axons. Nature 444: 369-373.

Panakova D, Sprong H, Marois E, Thiele C, Eaton S. 2005. Lipoprotein particles are required for Hedgehog and Wingless signalling. Nature 435: 58-65.

Park Y, Rangel C, Reynolds MM, Caldwell MC, Johns M, Nayak M, Welsh CJ, McDermott S, Datta S. 2003. Drosophila perlecan modulates FGF and hedgehog signals to activate neural stem cell division. Dev Biol 253: 247-257.

Parmantier E, Lynn B, Lawson D, Turmaine M, Namini SS, Chakrabarti L, McMahon AP, Jessen KR, Mirsky R. 1999. Schwann cell-derived Desert hedgehog controls the development of peripheral nerve sheaths. Neuron 23: 713-724.

Pepinsky RB, Zeng C, Wen D, Rayhorn P, Baker DP, Williams KP, Bixler SA, Ambrose CM, Garber EA, Miatkowski K, et al. 1998. Identification of a palmitic acid-modified form of human Sonic hedgehog. I Biol Chem 273: 14037-14045.

Pepinsky RB, Rayhorn P, Day ES, Dergay A, Williams KP, Galdes A, Taylor FR, Boriack-Sjodin PA, Garber EA. 2000. Mapping sonic hedgehog-receptor interactions by steric interference. I Biol Chem 275: 10995-11001.

Perler FB. 1998. Protein splicing of inteins and hedgehog autoproteolysis: Structure, function, and evolution. Cell 92: 1-4.

Plotnikov AN, Schlessinger J, Hubbard SR, Mohammadi M. 1999. Structural basis for FGF receptor dimerization and activation. Cell 98: 641-650.

Pons S, Marti E. 2000. Sonic hedgehog synergizes with the extracellular matrix protein vitronectin to induce spinal motor neuron differentiation. Development 127: 333-342.

Porter JA, von Kessler DP, Ekker SC, Young KE, Lee JJ, Moses K, Beachy PA. 1995. The product of hedgehog autoproteolytic cleavage active in local and long-range signalling. Nature 374: 363-366.

Porter JA, Young KE, Beachy PA. 1996. Cholesterol modification of hedgehog signaling proteins in animal development. Science 274: 255-259.

Riddle RD, Johnson RL, Laufer E, Tabin C. 1993. Sonic hedgehog mediates the polarizing activity of the ZPA. Cell 75: 14011416.

Roelink H, Augsburger A, Heemskerk J, Korzh V, Norlin S, Ruiz i Altaba A, Tanabe Y, Placzek M, Edlund T, Jessell TM, et al. 1994. Floor plate and motor neuron induction by vhh-1, a vertebrate homolog of hedgehog expressed by the notochord. Cell 76: 761-775.

Rohatgi R, Milenkovic L, Scott MP. 2007. Patched1 regulates hedgehog signaling at the primary cilium. Science 317:372-376.

St-Jacques B, Hammerschmidt M, McMahon AP. 1999. Indian hedgehog signaling regulates proliferation and differentiation of chondrocytes and is essential for bone formation. Genes Dev 13: 2072-2086.

Stone DM, Hynes M, Armanini M, Swanson TA, Gu Q, Johnson RL, Scott MP, Pennica D, Goddard A, Phillips H, et al. 1996. The tumour-suppressor gene patched encodes a candidate receptor for Sonic hedgehog. Nature 384: 129-134.

Tabata T, Eaton S, Kornberg TB. 1992. The Drosophila hedgehog gene is expressed specifically in posterior compartment cells and is a target of engrailed regulation. Genes Dev 6: 26352645.
Taipale J, Cooper MK, Maiti T, Beachy PA. 2002. Patched acts catalytically to suppress the activity of Smoothened. Nature 418: 892-897.

Tashiro S, Michiue T, Higashijima S, Zenno S, Ishimaru S, Takahashi F, Orihara M, Kojima T, Saigo K. 1993. Structure and expression of hedgehog, a Drosophila segment-polarity gene required for cell-cell communication. Gene 124: 183-189.

Tenzen T, Allen BL, Cole F, Kang JS, Krauss RS, McMahon AP. 2006. The cell surface membrane proteins Cdo and Boc are components and targets of the Hedgehog signaling pathway and feedback network in mice. Dev Cell 10: 647-656.

The I, Bellaiche Y, Perrimon N. 1999. Hedgehog movement is regulated through tout velu-dependent synthesis of a heparan sulfate proteoglycan. Mol Cell 4: 633-639.

Tsai MT, Cheng CJ, Lin YC, Chen CC, Wu AR, Wu MT, Hsu CC, Yang RB. 2009. Isolation and characterization of a secreted, cell-surface glycoprotein SCUBE2 from humans. Biochem J 422: 119-128.

van den Heuvel M, Ingham PW. 1996. smoothened encodes a receptor-like serpentine protein required for hedgehog signalling. Nature 382: 547-551.

Varjosalo M, Taipale J. 2008. Hedgehog: Functions and mechanisms. Genes Dev 22: 2454-2472.

Wang LC, Liu ZY, Gambardella L, Delacour A, Shapiro R, Yang J, Sizing I, Rayhorn P, Garber EA, Benjamin CD, et al. 2000. Conditional disruption of hedgehog signaling pathway defines its critical role in hair development and regeneration. I Invest Dermatol 114: 901-908.

Williams EH, Pappano WN, Saunders AM, Kim MS, Leahy DJ, Beachy PA. 2010. Dally-like core protein and its mammalian homologues mediate stimulatory and inhibitory effects on Hedgehog signal response. Proc Natl Acad Sci 107: 5869-5874.

Wilson CW, Chuang PT. 2006. New 'hogs' in Hedgehog transport and signal reception. Cell 125: 435-438.

Yam PT, Langlois SD, Morin S, Charron F. 2009. Sonic hedgehog guides axons through a noncanonical, Src-family-kinase-dependent signaling pathway. Neuron 62: 349-362.

Yan D, Lin X. 2008. Opposing roles for glypicans in Hedgehog signalling. Nat Cell Biol 10: 761-763.

Yan D, Lin X. 2009. Shaping morphogen gradients by proteoglycans. Cold Spring Harb Perspect Biol 1: a002493. doi: 10.1101/cshperspect.a002493.

Yan D, Wu Y, Yang Y, Belenkaya TY, Tang X, Lin X. 2010. The cell-surface proteins Dally-like and Ihog differentially regulate Hedgehog signaling strength and range during development. Development 137: 2033-2044.

Yao S, Lum L, Beachy P. 2006. The ihog cell-surface proteins bind Hedgehog and mediate pathway activation. Cell 125: 343-357.

Zeng X, Goetz JA, Suber LM, Scott WJ Jr, Schreiner CM, Robbins DJ. 2001. A freely diffusible form of Sonic hedgehog mediates long-range signalling. Nature 411: 716-720.

Zhang XM, Ramalho-Santos M, McMahon AP. 2001. Smoothened mutants reveal redundant roles for Shh and Ihh signaling including regulation of $\mathrm{L} / \mathrm{R}$ symmetry by the mouse node. Cell 106: 781-792.

Zhang W, Kang JS, Cole F, Yi MJ, Krauss RS. 2006. Cdo functions at multiple points in the Sonic Hedgehog pathway, and Cdodeficient mice accurately model human holoprosencephaly. Dev Cell 10: 657-665.

Zhang F, McLellan JS, Ayala AM, Leahy DJ, Linhardt RJ. 2007. Kinetic and structural studies on interactions between heparin or heparan sulfate and proteins of the hedgehog signaling pathway. Biochemistry 46: 3933-3941.

Zheng X, Mann RK, Sever N, Beachy PA. 2010. Genetic and biochemical definition of the Hedgehog receptor. Genes Dev 24: $57-71$. 


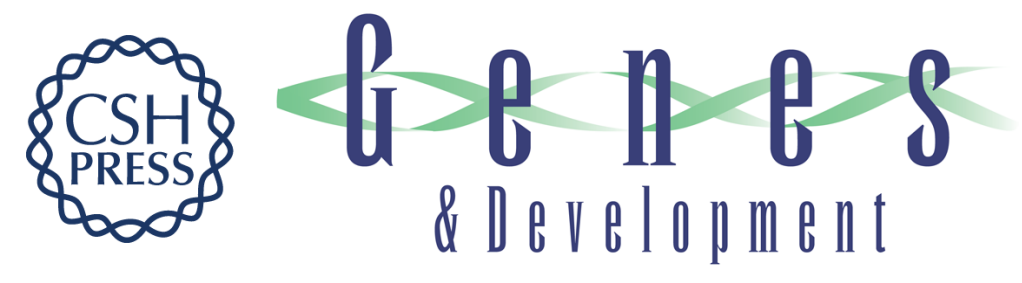

\section{Interactions between Hedgehog proteins and their binding partners come into view}

Philip A. Beachy, Sarah G. Hymowitz, Robert A. Lazarus, et al.

Genes Dev. 2010, 24:

Access the most recent version at doi:10.1101/gad.1951710

References This article cites 107 articles, 38 of which can be accessed free at: http://genesdev.cshlp.org/content/24/18/2001.full.html\#ref-list-1

License

Email Alerting Service

Receive free email alerts when new articles cite this article - sign up in the box at the top right corner of the article or click here.

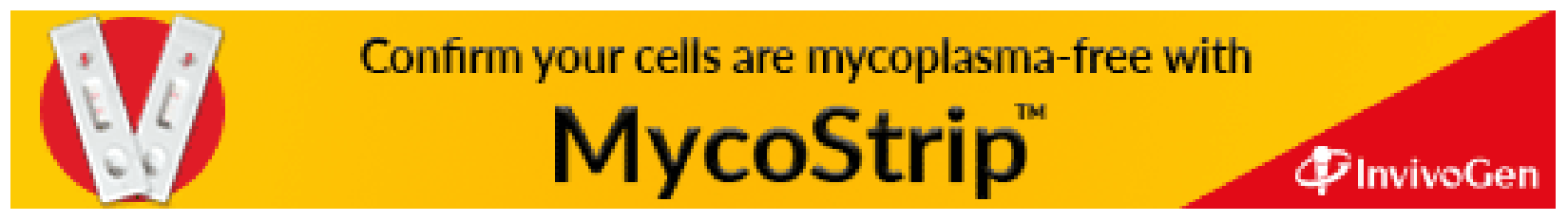

